American Journal of Pharmacology and Toxicology 4 (2):38-45, 2009

ISSN 1557-4962

(C) 2008 Science Publications

\title{
Effect of Intravenous Ketamine Administration on Blood Glucose Levels in Conscious Rabbits
}

\author{
${ }^{1}$ Suleiman I. Sharif and ${ }^{2}$ Hanan A. Abouazra \\ ${ }^{1}$ Department of Pharmacology, College of Pharmacy, University of Sharjah, UAE \\ ${ }^{2}$ Department of Biology, Faculty of Science, University of Waterloo, \\ 200 University Avenue West, Waterloo, Ontario, Canada N2L 3G1
}

\begin{abstract}
Problem statement: The intravenous general anaesthetic ketamine has been shown to produce changes in blood glucose levels. It is important to study the pharmacological basis of such an effect. Approach: The influence of varying doses of ketamine administered intravenously was studied in conscious rabbits. Serum glucose was determined by blood glucose method using an enzymatic PAP $_{250}$ kit. Results: Low doses of ketamine $\left(166.6 \mathrm{mg} \mathrm{kg}^{-1}\right)$ produced hyperglycaemia while higher doses ( 1 and $2 \mathrm{mg} \mathrm{kg}^{-1}$ ) produced hypoglycaemia. However, at even a higher dose, ketamine $\left(4 \mathrm{mg} \mathrm{kg}^{-1}\right)$ did not influence blood glucose levels. The dual effect of ketamine was resistant to $\alpha_{1}$-adrenoceptor blockade by WB-4101. On the other hand, the opioid antagonist naloxone blocked the hypoglycaemic and potentiated the hyperglycaemic effects of ketamine. Blockade of $\alpha_{2}$-adrenoceptors by yohimbine, abolished hyperglycaemia by ketamine and reversed its hypoglycaemic effect into hyperglycaemia that was sensitive to blockade by propranolol. Conclusion: Ketamine had a dual effect on blood glucose level. Its hyperglycaemic effect seemed to be mediated through $\alpha_{2}$-adrenoceptors while the hypoglycaemic effect is possibly mediated through opioid receptors with an involvement of $\beta$ adrenoceptors that only become evident after blockade of $\alpha_{2}$-adrenoceptors. Similar mechanisms may operate during ketamine anaesthesia. Plans were under preparations for future investigations on blood glucose levels of patients undergoing dental surgical procedures under ketamine anaesthesia, the results of which may prove clinically important.
\end{abstract}

Key words: Ketamine, conscious rabbits, blood glucose, intravenous

\section{INTRODUCTION}

Ketamine, a phencyclidine derivative, is widely used as a general Intravenous (i.v.) anaesthetic agent ${ }^{[1]}$. Good analgesia and maintenance of many protective reflexes characterize the anaesthetic properties of ketamine $^{[1,2]}$ The properties of ketamine differ from other general anaesthetics (1) and have led ketamine along with phencyclidine and other related agents to be classified as dissociative anaesthetics ${ }^{[3]}$. Both anaesthesia and surgery has been reported to affect blood glucose levels in humans ${ }^{[4]}$ ketamine anaesthesia appears to produce a significant elevation of blood glucose level in humans, during gynecological laparatomy ${ }^{[5]}$ and heart surgery ${ }^{[6]}$. Furthermore, the same effect has been reported in rats ${ }^{[7,8]}$ and baboon ${ }^{[9]}$.

Surgical procedures evoke an endocrine response and changes metabolism towards catabolism and it has been suggested that the endocrine response to anaesthesia is less than that to major surgical procedures $^{[10,11]}$. The same authors suggested that blood sugar rises during surgery to an extent depending much more on the degree of stress than the type of anaesthesia and the lighter the anaesthesia the greater the bood sugar response. Thus, it seems rather difficult to pinpoint with certainty the influence of the anaesthetics themselves among other variables such as the effects of the duration of the surgical operation ${ }^{[12,13]}$ and stress ${ }^{[12]}$ on blood glucose level. This study was designed to elucidate the effects of i.v. ketamine on blood glucose level in conscious rabbits and the possible mechanisms contributing to such effects.

\section{MATERIALS AND METHODS}

Animals: Healthy adult male New Zealand white rabbits, average age 3 months, weighing between 2.5-3.0 kg, bred in the animal house of the Al-Arab

Correspondence Author: Suleiman I. Sharif, College of Pharmacy, University of Sharjah, 27272 Sharjah, UAE Tel: 00971-6-5057406 Fax: 00971-6-5585812 
Medical University, Benghazi, Libya, were used. Animals in all experiments were provided with a standard laboratory diet and had free access to tap water. The rooms in which they were housed were maintained at $22-23^{\circ} \mathrm{C}$ on a $12 \mathrm{~h}$ light/dark cycle. Al-Arab Medical University Animal Care and Use Committee approved all procedures carried out in this study.

Drugs: Drugs used in this study were ketamine $\mathrm{HCl}$, Propranolol, yohimbine $\mathrm{HCl}$ (Sigma Chemical Co., St Louis, Mo, USA), naloxone $\mathrm{HCl}$ (Antigen, Roscrea, Ireland) and WB- $4101 \mathrm{HCl}(\{2-(2,6$-dimethoxy phenoxy ethyl) amino ethyl-1, 4 -benzodioxane] hydrochloride; Funakoshi, Tokyo, Japan) was obtained as powder. Saline $(0.9 \% \mathrm{NaCl}$ solution) was used as a vehicle for both naloxone and ketamine, while distilled water was used as a vehicle for yohimbine, propranolol and WB-4101.

Study protocol: Food was withdrawn $24 \mathrm{~h}$ before the start of each experiment. Control samples of blood were withdrawn at an interval of $30 \mathrm{~min}$ before the injection of a drug and the mean of these samples was taken as the control blood glucose level. Intravenous injections were made through the marginal ear vein and blood samples were collected in tubes, which were immediately centrifuged for $5 \mathrm{~min}$ at $3000 \mathrm{rpm}$ to obtain serum. After collection, a digital pressure was applied to the collection site until bleeding has stopped and the ear was cleaned. If the rabbit was used for more than one experiment, an interval of at least seven days was allowed before the second experiment. Serum glucose level was determined by blood glucose oxidase method using Bio-Merieux enzymatic PAP $_{250}$ kits (Sigma Chemical Co., St Louis, Mo, USA). The color intensity was read on a Beckman spectrophotometer at 505 nm-wave length. Al-arab Medical University Animal care and Use Committee approved all procedures performed in this study.

Statistical analysis: Results are expressed as mean \pm SEM of " $n$ " observations, where " $n$ " represents the number of animals used. Statistical analysis was performed using the One-Way Analysis Of Variance (ANOVA) to compare among the groups for overall differences. A paired Student's t-test was used to compare between the test groups and control. A level of significance of $\mathrm{p}<0.05$ was accepted.

\section{RESULTS}

Blood glucose level of unanaesthetized naive rabbits: In our experiments, New Zealand white rabbits that were apparently healthy and were not previously exposed to any drug treatment had an average fasting blood glucose level of $94.6 \pm 0.54 \mathrm{mmol} \mathrm{L}^{-1}(\mathrm{n}=120)$ and ranged between 80.2-110.4. No significant changes were observed in response to i.v. administration of $1 \mathrm{ml}$ of either saline or distilled water, so that they were used as vehicles for all drugs used in this study.

Effect of intravenously administered ketamine: As shown in (Fig. 1a), ketamine at total doses of 50 and $200 \mu \mathrm{g}$, (16.66 and $66.6 \mu \mathrm{g} \mathrm{kg}^{-1}$,respectively) produced no significant changes in blood glucose level. However, a higher dose of ketamine, $500 \mu \mathrm{g}$, (166.6 $\left.\mu \mathrm{g} \mathrm{kg} \mathrm{kg}^{-1}\right)$ produced hyperglycaemia that was only significant $(\mathrm{p}<0.01)$ at 15 and $30 \mathrm{~min}$ following it's administration. With further increases in the dose of ketamine to 1 and $2 \mathrm{mg} \mathrm{kg}{ }^{-1}$, a hypoglycaemic response was observed (Fig. 1b). The decrease in blood glucose level was maximum at $15 \mathrm{~min}$ for ketamine $\left(1 \mathrm{mg} \mathrm{kg}^{-1}\right)$, but at $60 \mathrm{~min}$ for ketamine $\left(2 \mathrm{mg} \mathrm{kg}^{-1}\right)$. Two hours later,

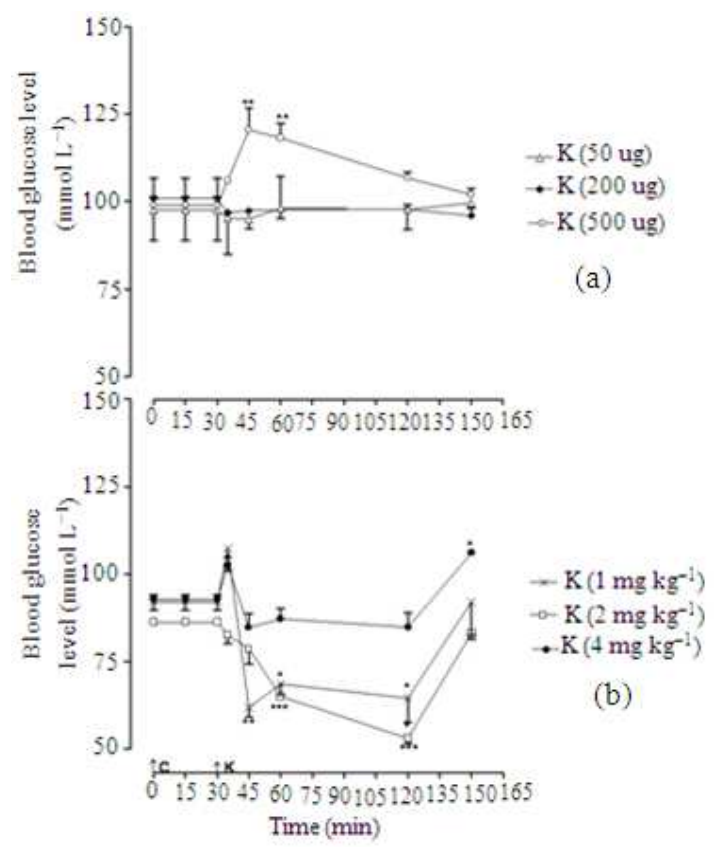

Fig. 1: Effect of ketamine on blood glucose level of conscious rabbits. Fasted animals received vehicle, C, (i.v.), followed $30 \mathrm{~min}$ later by increasing dose of ketamine (K) given i.v. 50, 200 and $500 \mu \mathrm{g}, 1,2$ and $4 \mathrm{mg} \mathrm{kg}^{-1}$. Each point represents mean of results from 8 rabbits. Vertical lines present SEM. Asterisks indicate significant difference from control *: $\mathrm{p}<0.05$, **: $\mathrm{p}<0.01$, ***: $\mathrm{p}<0.005$, Student's t-test 
Am. J. Pharm. \& Toxicol., 4 (2):38-45, 2009

Table 1: Effect of i.v. ketamine given alone and in the presence of naloxone on blood glucose levels in conscious rabbits

\begin{tabular}{|c|c|c|c|c|c|c|c|}
\hline \multirow[b]{2}{*}{ Drug regimen used } & \multirow{2}{*}{$\begin{array}{l}\text { No. of } \\
\text { animals }\end{array}$} & \multirow{2}{*}{$\begin{array}{l}\text { Control } \\
\text { (0) min }\end{array}$} & \multicolumn{5}{|c|}{ Minutes after drug injection } \\
\hline & & & 5 & 15 & 30 & $60^{\circ}$ & $120^{\prime}$ \\
\hline Ketamine $(500 \mu \mathrm{g})$ & 5 & $93.4 \pm 3.10$ & $106.0 \pm 0.2$ & $120.5 \pm 6.4$ & $118.2 \pm 4.10$ & $106.7 \pm 1.8$ & $102.0 \pm 1.76$ \\
\hline Ketamine $\left(4 \mathrm{mg} \mathrm{Kg}^{-1}\right)$ & 5 & $94.8 \pm 1.20$ & $96.4 \pm 2.4$ & $94.7 \pm 4.0$ & $97.2 \pm 3.00$ & $94.8 \pm 4.2$ & $106.0 \pm 0.80$ \\
\hline Naloxone $\left(0.25 \mathrm{mg} \mathrm{kg}^{-1}\right)$ & 5 & $95.5 \pm 8.60$ & $96.0 \pm 6.4$ & $95.3 \pm 2.0$ & $96.2 \pm 5.70$ & $95.0 \pm 2.9$ & $95.0 \pm 2.80$ \\
\hline Naloxone $\left(1 \mathrm{mg} \mathrm{kg}^{-1}\right)$ & 5 & $93.5 \pm 0.80$ & $101.0 \pm 1.2$ & $118.3 \pm 1.3$ & $119.9 \pm 1.50$ & $110.2 \pm 1.3$ & $103.0 \pm 4.70$ \\
\hline $\begin{array}{l}\text { Naloxone }(0.25 \mathrm{mg} \mathrm{kg})^{-1} \\
\text { Ketamine }(500 \mu \mathrm{g})\end{array}$ & 6 & $96.0 \pm 2.20$ & $98.0 \pm 2.8$ & $119.4 \pm 0.2$ & $120.2 \pm 1.80$ & $106.9 \pm 1.6$ & $104.3 \pm 1.90$ \\
\hline $\begin{array}{l}\text { Naloxone }\left(1 \mathrm{mg} \mathrm{kg}^{-1}\right) \\
+ \text { Ketamine }(500 \mu \mathrm{g})\end{array}$ & 6 & $118.7 \pm 1.20$ & $120.0 \pm 4.1 * * *$ & $122.0 \pm 0.2$ & $124.0 \pm 0.80 * * *$ & $118.9 \pm 1.2 * * *$ & $113.0 \pm 0.60$ \\
\hline $\begin{array}{l}\text { Naloxone }\left(1 \mathrm{mg} \mathrm{kg}^{-1}\right) \\
+ \text { Ketamine }\left(4 \mathrm{mg} \mathrm{kg}^{-1}\right)\end{array}$ & 6 & $118.0 \pm 0.80$ & $133.2 \pm 1.4 * * *$ & $136.5 \pm 0.6 * * *$ & $194.1 \pm 3.50 * * *$ & $163.0 \pm 1.8 * * *$ & $151.1 \pm 0.90 * * *$ \\
\hline
\end{tabular}

Fasted rabbits received either i.v. injection of the vehicle or naloxone. Control blood samples were withdrawn at 0, 15, 30 min (the mean was taken as 0 min control value), followed by either i.v. ketamine or naloxone depending on the regimen applied. Data are expressed as mean \pm SEM Statistically significant differences are compared with ketamine not pre-treated with naloxone and represented as $* *$ : $\mathrm{p}<0.01 ; * * * \mathrm{p}<0.005$

blood glucose levels were not different from the predrug level for both doses. At a higher dose of ketamine (4 $\mathrm{mg} \mathrm{kg}^{-1}$ ), no significant changes were observed in blood glucose level up to $1 \mathrm{~h}$, but blood glucose level was significantly $(\mathrm{p}<0.05)$ raised at $2 \mathrm{~h}$. However, at the high doses of ketamine (1-4 $\mathrm{mg} \mathrm{kg}^{-1}$, i.v.) tested all rabbits exhibited excitation and teeth chattering that lasted for only $5 \mathrm{~min}$.

Effect of intravenous ketamine in the presence of naloxone: As it can be shown in Table 1, naloxone $\left(0.25 \mathrm{mg} \mathrm{kg}^{-1}\right)$ produced no effect of it's own and when given $30 \mathrm{~min}$ earlier, it did not affect the hyperglycaemia in response to ketamine (500 $\mu \mathrm{g}$, i.v.). However, naloxone (1 $\mathrm{mg} \mathrm{kg}^{-1}$, i.v.), a dose which usually produces hyperglycaemia, when it is given 30 min prior to ketamine $(500 \mu \mathrm{g}$, i.v.), it significantly $(\mathrm{p}<0.005)$ potentiated the hyperglycaemic effect in response to ketamine at 5, 30 and $60 \mathrm{~min}$. after ketamine injection. Interestingly, the highest dose of ketamine $\left(4 \mathrm{mg} \mathrm{kg}^{-1}\right.$, i.v.) tested that was without any effect on blood glucose levels, seems to potentiate the hyperglycaemic effect of naloxone $\left(1 \mathrm{mg} \mathrm{kg}^{-1}\right)$-as in the presence of ketamine, naloxone produced much greater rise in blood glucose levels than that produced in the absence of ketamine. In experiments, to test the influence of naloxone (1 $\mathrm{mg} \mathrm{kg}^{-1}$, i.v.) on hypoglycaemia-induced by ketamine $\left(2 \mathrm{mg} \mathrm{kg}^{-1}\right.$, i.v. $)$, no changes were observed in blood glucose and the effects produced by each drug alone were lost (Fig. 2).

Effect of intravenous ketamine in the presence of WB-4101: The selective $\alpha_{1}$ adrenoceptor antagonist (WB-4101) given in a dose of $(50 \mu \mathrm{g}, \mathrm{i} . \mathrm{v}$. $)$ produced no significant changes in blood glucose levels in unanaesthetized rabbits. Pretreatment with WB-4101 was without effect on both hyperglycaemia in response to low $(500 \mu \mathrm{g}$, i.v.) and hypoglycaemia to high (2 $\mathrm{mg} \mathrm{kg}^{-1}$, i.v.) doses of ketamine.

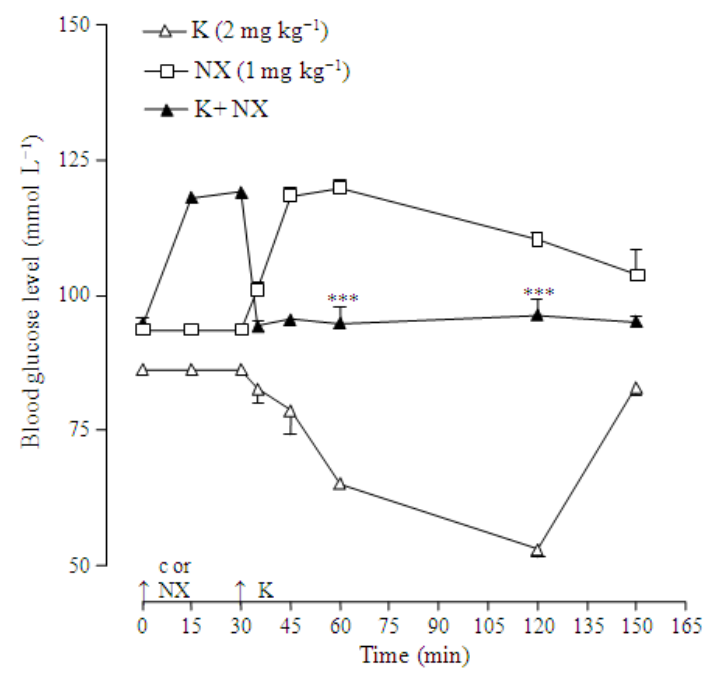

Fig. 2: Blockade of ketamine-induced hypoglycaemia by naloxone. Fasted rabbits received i.v. injection of vehicle, $\mathrm{C}$, followed $30 \mathrm{~min}$ later by i.v. ketamine, $\mathrm{K}$, $\left(2 \mathrm{mg} \mathrm{kg}^{-1}\right)$, or i.v. naloxone, $\mathrm{NX},\left(1 \mathrm{mg} \mathrm{kg}^{-1}\right)$, followed $30 \mathrm{~min}$ later by i.v. ketamine $\left(2 \mathrm{mg} \mathrm{kg}^{-1}\right)$. Each point represents mean of results from 6 rabbits. Vertical lines represent SEM. Asterisks indicate significant difference from control ***: $\mathrm{p}<0.005$. Student's t-test

Effect of intravenous ketamine in the presence of yohimbine: Yohimbine $\left(1 \mathrm{mg} \mathrm{kg}^{-1}\right.$, i.v.) produced no significant changes in blood glucose levels, but when given $30 \mathrm{~min}$ prior to ketamine (500 $\mu \mathrm{g}$, i.v.), it completely blocked the hyperglycaemic response to the later drug (Fig. 3). However, both yohimbine (1) and ketamine (4 $\mathrm{mg} \mathrm{kg}^{-1}$, i.v.) were without any appreciable effect on blood glucose, whether each was administered alone or when both drugs were combined and no 
Am. J. Pharm. \& Toxicol., 4 (2):38-45, 2009

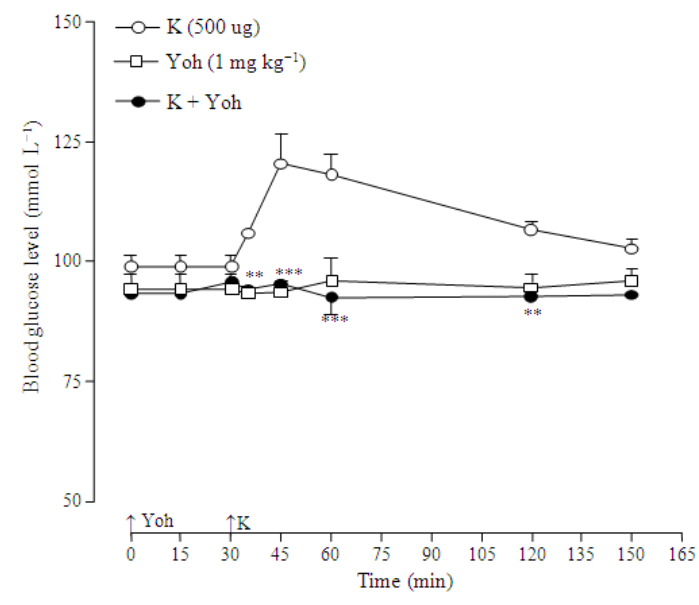

Fig. 3: Blockade of ketamine-induced hyperglycaemia by yohimbine. Fasted rabbits received i.v. injection of the vehicle, $\mathrm{C}$, followed $30 \mathrm{~min}$ later by i.v. ketamine, $\mathrm{K}$, $(500 \mu \mathrm{g})$, or i.v. yohimbine, Yoh, $\left(1 \mathrm{mg} \mathrm{kg}^{-1}\right)$, followed $30 \mathrm{~min}$ later by i.v. ketamine, $\mathrm{K},(500 \mu \mathrm{g})$. Each point represents mean of results from 6 rabbits. Vertical lines represent SEM. Asterisks indicate significant difference from control. $* *$ : $\mathrm{p}<0.01$, $* * *$ : $\mathrm{p}<0.005$. Student's t-test

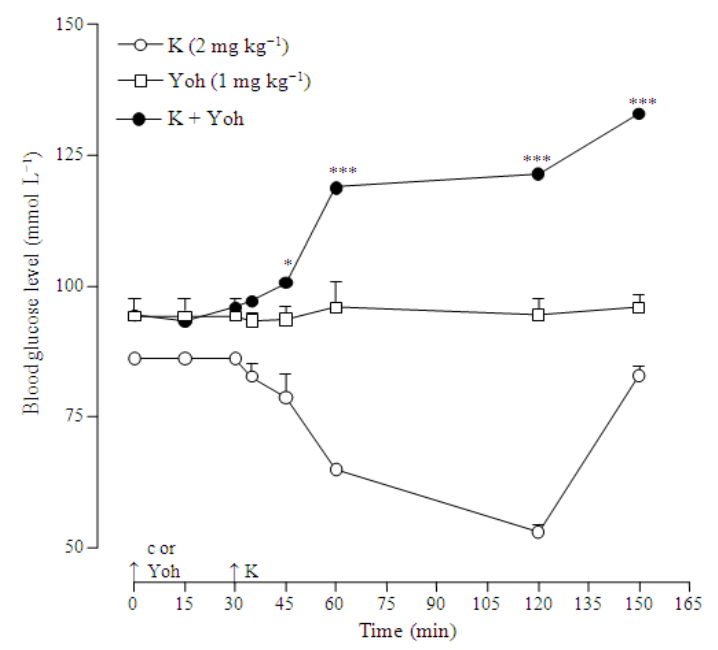

Fig. 4: Reversal of ketamine-induced hypoglycaemia by yohimbine. Fasted rabbits received i.v. injection of vehicle, $\mathrm{C}$, followed $30 \mathrm{~min}$ later by i.v. ketamine, $\mathrm{K},\left(2 \mathrm{mg} \mathrm{kg}^{-1}\right)$, or i.v. yohimbine, Yoh, $\left(1 \mathrm{mg} \mathrm{kg}^{-1}\right)$, followed $30 \mathrm{~min}$ later by i.v. ketamine $\left(2 \mathrm{mg} \mathrm{kg}^{-1}\right)$. Each point represents mean of results from 6 rabbits. Vertical lines represent SEM. Asterisks indicate significant difference from control, *: $\mathrm{p}<0.05, * * *$ : $\mathrm{p}<0.005$. Student's t-test

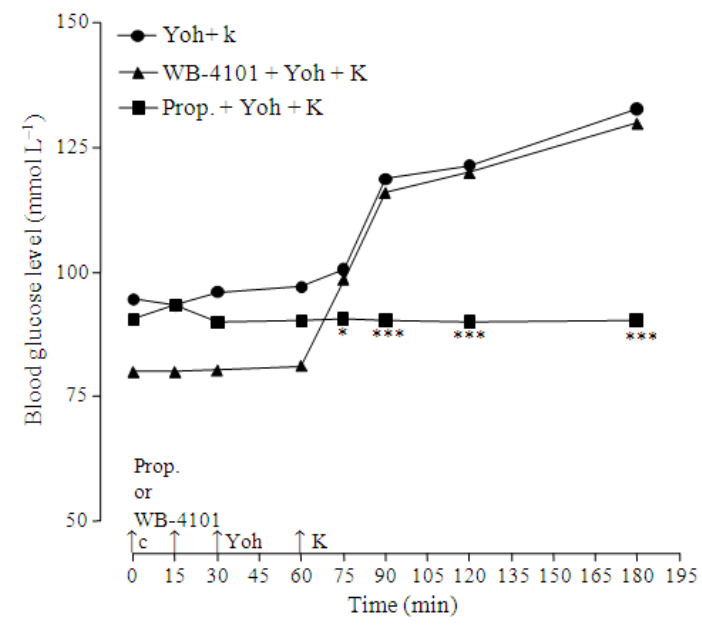

Fig. 5: Effect of propranolol and WB-4101 on the reversal of ketamine-induced hypoglycaemia by yohimbine. In these experiments, two control blood samples were withdrawn at 0,15 min and immediately propranolol or WB-4101 was given, followed $15 \mathrm{~min}$ later by yohimbine and at $60 \mathrm{~min}$, ketamine was given. All injections were given i.v. to fasted rabbits. Each point represents mean of results from 6 rabbits. Vertical lines represent SEM. Asterisks indicate significant difference from control, *: $\mathrm{p}<0.01$, ***: $\mathrm{p}<0.005$. Student's t-test

behavioral changes were observed with any of these treatment schedules. In the presence of yohimbine ( $1 \mathrm{mg} \mathrm{kg}^{-1}$, i.v.), the hypoglycaemia in response to ketamine (2 $\mathrm{mg} \mathrm{kg}^{-1}$, i.v.) was reversed into a significant hyperglycaemia that persisted up to $2 \mathrm{~h}$ (Fig. 4)). Reversal of ketamine (2 $\mathrm{mg} \mathrm{kg}^{-1}$, i.v.)induced hypoglycaemia by yohimbine $\left(1 \mathrm{mg} \mathrm{kg}^{-1}\right.$, i.v. $)$ was not influenced by pretreatment with the $\alpha_{1}$ adrenoceptor antagonist WB-4101 (50 $\mu \mathrm{g} \mathrm{kg}^{-1}$, i.v.) given $15 \mathrm{~min}$ before yohimbine. However, in the presence of the non-selective $\beta$-adrenoceptor antagonist propranolol $\left(1 \mathrm{mg} \mathrm{kg}^{-1}\right)$ yohimbine was without any effect on ketamine-induced hypoglycaemia (Fig. 5).

\section{DISCUSSION}

Ketamine anaesthesia appears to produce a significant elevation of blood glucose level during surgery ${ }^{[5,6]}$. It has been suggested that the hyperglycaemic response to surgery was related to the duration of the surgical operation and the extent of it's stress $^{[12,14]}$. Our preliminary results ascertained that the observed changes in blood glucose level are not a 
consequence of stress as changes in response to i.v. ketamine are dose-dependent and can occur in either direction. In addition, at certain dosage level, ketamine did not alter control blood glucose levels. In our experiments, Ketamine at doses of 50 and $200 \mu \mathrm{g}$ (16.66, $66.6 \mu \mathrm{g} \mathrm{kg}^{-1}$ ) was without effect on blood glucose levels. Only on increasing the dose of i.v. ketamine to $500 \mu \mathrm{g}\left(166.6 \mu \mathrm{g} \mathrm{kg}^{-1}\right)$, a significant rise in blood glucose was evident at 15 and 30 min following drug administration. This result recalls similar observations with ketamine in children ${ }^{[15]}$ and rats ${ }^{[16]}$ and ketamine-xylazine in rabbits ${ }^{[17]}$. Surprisingly, further increase in the dose of ketamine to (1 and $2 \mathrm{mg} \mathrm{kg}{ }^{-1}$ ) led to the precipitation of marked hypoglycaemia. Interestingly, at a higher dose tested, ketamine $\left(4 \mathrm{mg} \mathrm{kg}^{-1}\right)$, was without effect and blood glucose level remained unchanged This adds further support to the point that ketamine may have a dual effect on blood glucose level. In this context, it is interesting to mention that it has been previously suggested that ketamine, like cocaine, possesses the dual properties of neuronal noradrenaline uptake blockade and local anaesthetic-type depression of synaptic transmission, however, whereas cocaine possesses the former property at low doses and the latter at high doses, while for ketamine, the optimal doses for each property are rather close and, therefore, the net effect will depend on the system under investigation $^{[18]}$. This suggestion, however, does not explain our observations of hyperglycaemia in response to low and hypoglycaemia to high doses and lack of effect to the highest dose tested of ketamine. Thus, we suggest that ketamine may possibly act on two sites with different activation thresholds and mediate opposite effects. Depending on the dose of the drug and the sensitivity of the site, ketamine can produce either hyper or hypoglycaemia, but at a certain dose level of ketamine both sites become operant and a state of balance is achieved with the net result no alteration of blood glucose level. It seems rather difficult to pinpoint with certainty the exact sites at which ketamine either directly or indirectly act to produce changes in blood glucose levels of conscious fasted rabbits.

As analgesic ketamine has been reported to act as an agonist at opiate receptors ${ }^{[19]}$. It has also been suggested that ketamine along with phencyclidine binds to, at least, two distinct sites, sigma opiate sites that mediate naloxone-insensitive psychomimetic effects of certain opioids and (phencyclidine) PCP-preferring site that is located within N-Methyl-D-Aspartate (NMDA) receptor ion channel and appears to inhibit the flux of cations, particularly $\mathrm{Ca}^{+2}$, that is initiated by glutamate and/or aspartate ${ }^{[20]}$. Ketamine has also been shown to have both inhibitory and excitatory effects on the peripheral nervous system ${ }^{[18,21]}$. More recently ${ }^{[16]}$ claimed that acute hyperglycaemia induced by a mixture of ketamine and xylazine is mediated by modulation of the glucoregulatory hormones through stimulation of $\alpha_{2}$-adrenoceptors.

In the present study, we subjected both the hyperand hypo-glycaemic effects of ketamine to analysis using the opiod antagonist naloxone. In agreement with others $^{[22,23]}$, we also observed that naloxone produced a functional synergism. This is further substantiated by the observation that the same dose of naloxone while loosing it's effect, it completely abolished hypoglycaemia in response to i.v. ketamine $\left(2 \mathrm{mg} \mathrm{kg}^{-1}\right)$. Moreover, hyperglycaemia in response to naloxone (1 $\mathrm{mg} \mathrm{kg}^{-1}$, i.v.) was markedly potentiated in the presence of the highest dose of ketamine tested that was without any effect of it's own on blood glucose levels. Since, hyperglycaemia in response to intravenous ketamine is not blocked by a non-hyperglycaemic dose of naolxone and since combination of hyperglycaemic doses of both drugs is synergistic, it seems possible that ketamine might be acting on either non-opioid, possibly PCP/NMDA or adrenegic receptors, to produce hyperglycaemia or it acts on a sub-population of opioid receptors that are resistant to naloxone, like $\sigma$-site mediating naloxone-insensitive effects ${ }^{[24]}$.

The possibility that ketamine-induced hyperglycaemia may be mediated via activation of $\alpha_{2}-$ adrenoceptors has to be considered. It is well established that catecholamines can produce hyperglycaemia in rabbits ${ }^{[25-27]}$. Like adrenaline and noradrenaline, the selective $\alpha_{1}$-agonist phenylephrine ${ }^{\text {[27] }}$ and the selective $\alpha_{2}$ - agonist clonidine ${ }^{[28-30]}$ have both been shown to produce hyperglycaemia. and hyperglycaemia in response to ketamine/xylazine mixture has been inhibited in a dose-dependent manner by the selective $\alpha_{2}$-adrenoceptor antagonist yohimbine $^{[16]}$ It has been suggested that in ketamine anaesthetized rats, both the inhibitory tone on insulin secretion and the glycogenolytic response are probably mediated by adrenergic innervation of the pancreas, liver and circulating catecholamines secreted from the adrenal meddula ${ }^{[31]}$. In the present study, the possible involvement of $\alpha_{1}$-adrenoceptors in mediating ketamine hyperglycaemia was explored by testing the effect of the latter drug in presence of the selective $\alpha_{1}$-antagonist WB-4101. Blockade of $\alpha_{1}$-adrenoceptors neither induced hyperglycaemia nor influenced that in response to ketamine. In addition, WB-4101 was also without effect on ketamine-induced hypoglycaemia. The failure of WB-4101 to block ketamine-induced hyperglycaemia recalls similar observation on failure of 
prazocin to antagonize hyperglycaemia in response to adrenaline in both mice and rabbits ${ }^{[32-34]}$. In addition, hyperglycaemia-induced by phenylephrine was only partially attenuated by prazocin ${ }^{[23]}$. It has also been reported that in rabbits, $\beta$-adrenoceptor blockade with propranolol failed to antagonize the increase in blood glucose caused by either adrenaline or noradrenaline ${ }^{[25,26]}$. Hyperglycaemia in response to adrenergic agonists have been claimed to involve the stimulation of $\alpha_{2}$-adrenoceptors ${ }^{[29,32,33,35,36]}$. It has also been shown that the selective $\alpha_{2}$-adrenoceptor agonist UK14304 increases blood glucose levels in conscious fasted rabbits when infused alone ${ }^{[37]}$. However, the effect was antagonized in rabbits previously treated with the $\alpha_{2}$-adrenoceptor antagonist 2methoxyidazoxan $^{[37]}$. Moreover, efaroxan, the $\alpha_{2^{-}}$ adrenoceptor antagonist, when given alone it had a little effect on blood glucose level but it markedly antagonized the hyperglycaemic actions of UK14304 and adrenaline. These results provided a further support for the involvement of $\alpha_{2}$-adrenoceptors in glucose homeostasis $^{[38]}$. In our experiments both the hyper- and hypoglycaemic effects of ketamine were resistant to blockade of $\alpha_{1}$-adrenoceptors with WB-4101. On the other hand, hyperglycaemia in response to i.v. ketamine was highly sensitive to yohimbine. These results clearly indicate that $\alpha_{2}$-adrenoceptors significantly contribute to the hyperglycaemic response to ketamine. Surprisingly, when we tested ketamine-induced hypoglycaemia in the presence of yohimbine, it was reversed into hyperglycaemia. This later effect was resistant to $\alpha_{1}$-adrenoceptor blockade with WB-4101, but highly sensitive to $\beta$-adrenoceptor blockade with propranolol. Taken together, the results may suggest that ketamine acts on $\alpha_{2}$-adrenoceptors to produce hypoglycaemia and blockade of such receptors, unmasks an effect on $\beta$-adrenoceptor leading to hyperglycaemia. Our results indicate that hyperglycaemia in response to ketamine may be mediated mainly via $\alpha_{2}$-adrenoceptors with opioid mechanisms playing only a minor role as the response was highly sensitive to blockade by yohimbine, but only partially reduced by naloxone. On the other hand, hypoglycaemia in response to ketamine may be mediated by an action on sites that are sensitive to both naloxone and yohimbine. Our observation that blockade of $\alpha_{2}$-adrenoceptors with yohimbine reverses the hypoglycaemia induced by ketamine into hyperglycaemia that is sensitive to propranolol may suggest that $\beta$-adrenoceptors becomes operant and their activation by ketamine would lead to hyperglycaemia, only after inactivation of $\alpha_{2}$-adrenoceptors. This view does not, however exclude a direct effect of ketamine on both $\alpha_{2}$ and $\beta$-adrenoceptors. Indeed, it has been suggested that the use of yohimbine to assess the role of $\alpha_{2}$-adrenoceptors at any of these sites in the intact animal requires care that the observed responses are solely due to blockade of $\alpha_{2}$-adrenoceptors and not to $\beta$-adrenergic effects of increased circulating catecholamines $^{[39]}$. It seems possible that hyperglycaemia in response to ketamine may be mediated mainly through activation of $\alpha_{2}$-adrenoceptors with opioid mechanisms playing only a minor role as the response was highly sensitive to blockade by yohimbine, but only partially reduced by naloxone. On the other hand, hypoglycaemia in response to ketamine may be mediated by an action on sites that are sensitive to both naloxone and yohimbine.

\section{CONCLUSION}

In summary, the present results clearly show a dose-dependent effect of ketamine on blood glucose levels in conscious rabbits. Low dose produces hyperglycaemia that is mediated via $\alpha_{2}$-adrenoceptors while high doses produce hypoglycaemia mediated through opioid receptors with some involvement of $\beta$ adrenoceptors that becomes evident only after blockade of $\alpha_{2}$-adrenoceptors.

\section{ACKNOWLEDGMENT}

This study is dedicated to the memory of the late Dr. A.K. Roychoudhury We are grateful to Mr. M. Mosa for his technical assistance, Mr. A. Subaih and Mr. E. Mohamed who were responsible for the care of the animals.

\section{REFERENCES}

1. Mc Carthy, D.A., G. Chen, D.H. kaump and I. Ensor, 1965. General anaesthetic and other pharmacological properties of 2-(o-chlorophenyl)2-methylamino-cyclohexanone $\mathrm{HCl}$ (CI-581). J. New Drugs, 5: 21-33. PMID: 14283065

2. Glen, J.B., 1973. The use of ketamine (CI-581) in feline anaesthetic practice. Vet. Res., 92: 65-68. PMID: 4686119

3. Corssen, G. and E.F. Domino, 1966. Dissociative anaesthesia: Further pharmacologic studies and first clinical experience with the phencyclidine derivative CI-581. Anaesth. Analg., 45: 29-40. PMID: 5325977 
4. Oyama, T. and T. Takazawa, 1971. Effects of diethylether anaesthesia and surgery on carbohydrate and fat metabolism in man. Can. Anaesth. Soc. J., 18: 51-59. PMID: 5545735

5. Kobori, M.H., K. Fukasawa and K. Gomi, 1971. Effects of anaesthesia on the metabolic response during pelvic surgery. Masui, 41: 721-726. PMID: 1608147

6. Malatinský, J., M. Vigas, D. Jezová, J. Jurcovicová, M. Sámel and D. Vrsanský, 1984. The effects of open heart surgery on growth hormone, cortisol and insulin levels in man. Hormone levels during open heart surgery. Resuscitation, 11: 57-68. PMID: 6322266

7. Reyes toso, C.F., L.M. Linares and R.R. Rodriguez, 1995. Blood sugar concentrations during ketamine or pentobarbitone anaesthesia in rats with or without alpha and beta adrenergic blockade. Med. (B Aires), 55: 311-316. PMID: 8728870

8. Simpson, D.P., 1997. Prolonged (12 h) intravenous anaesthesia in the rat. Lab. Anim. Sci., 47: 519-23. PMID: 9355095

9. Du Plooy, W.J., P.J. Schutte, J. Still, L. Hay and C.P. Kahler, 1998. Stability of cardiodynamic and some blood parameters in the baboon following intravenous anaesthesia with ketamine and diazepam. J. S. Afr. Vet. Assoc., 69: 18-21. PMID: 9646256

10. Goldenberg, I.S., M.A. Hayes and N.M. Greene, 1959. Endocrine responses during operative procedures. Ann. Surg., 150: 196-201. http://www.pubmedcentral.nih.gov/articlerender.fc gi? artid $=1613370$

11. Traynor, C. and G.M. Hall, 1981. Endocrine and metabolisc changes during surgery: Anaesthetic applications. Br. J. Anaesth., 53: 153-160. PMID: 7008816

12. Clarke, R.S., 1970. The hyperglycaemic response to different types of surgery and anaesthesia. Br. J. Anaesth., 42: 45-53. PMID: 5416307

13. Oyama, T., 1973. Endocrine responses to anaesthetic agents. Br. J. Anaesth., 45: 276-281. PMID: 4349270

14. Allison, S.P., P.J. Tomlin and M.J. Chamberlain, 1969. Some effects of anaesthesia and surgery on carbohydrate and fat metabolism. Br. J. Anaesth., 41: 588-593. PMID: 5798836

15. Kaniaris, P., D. Lekakis, M. Kykoniatis and E. Kastanas, 1975. Serum free fatty acid and blood sugar levels in children under halothane, thiopentone and ketamine anaesthesia (comparative study). Can. Anaesth. Soc. J., 22: 509-18. PMID: 1095162
16. Saha, J.K., J. XIA, J.M. Grondin, S.K. Engle and J.A. Jakubowski, 2005. Acute hyperglycemia induced by ketamine/xylazine anesthesia in rats: Mechanisms and implications for preclinical models. Exp. Biol. Med., 230: 777-784. PMID: 16246906

17. Chalabi, K., M. Schutte and M. Reim, 1987. Alterations of glucose levels in the blood and the anterior eye segment of rabbits exposed to ketamine-xylazine anaesthesia. Ophthal. Res., 19: 89-291. PMID: 3438048

18. Clanachan, A.S. and J.C. McGrath, 1976. Effects of ketamine on the peripheral autonomic nervous system of the rat. Br. J. Pharmacol., 58: 247-252. PMID: 974387

19. Smith, D.J., D.P. Westfall and J.D. Adams, 1980. Ketamine interacts with opiate receptors as an agonist. Anesthesiology, 53: S5. http://journals.lww.com/anesthesiology/Citation/19 80/09001/Ketamine_Interacts_With_Opiate_Recep tors_As_An.5.aspx

20. Monaghan, D.T., R.J. Bridges and C.W. Cotman, 1989. The excitatory amino acid receptors: Their classes, pharmacology and distinct properties in the function of central nervous system. Ann. Rev. Pharmacol. Toxicol., 29: 365-402. PMID: 2543272

21. Sinclair, J.G. and A.F. Tien, 1979. Neuronal response to ketamine administered microiontophoretically or intraperitoneally in the rats. Gen. Pharmacol., 10: 51-55. DOI: 10.1016/0306-3623(79)90029-6

22. Feldberg, W., D.A. Pyke and W.A. Stubbs, 1983. Hyperglycaemia, a morphine-like effect produced by naloxone in the cat. J. Physiol., 340: 121-128. PMID: 6887043

23. Abouazra, H.A. and S.I. Sharif Hyperglycaemia, 2001. A morphine like effect produced by naloxone. J. Clin. Exp. Pharmacol. Physiol., 28: 300-305. PMID: 11251644

24. Largent, B.L., H. Wikstrom and A.L. Gundlach, 1987. Structural determinants of sigma affinity. Mol. Pharmacol., 32: 772-784. PMID: 2826991

25. Potter, D.E., J. Moratinos and S. Ellis, 1974. Comparative hyperglycaemic responses to norepinephrine, salbutamol and glucagon in normal and alloxan diabetic insulin-controlled rabbits. Arch. Int. Pharmacodyn. Ther., 209: 358-368. PMID: 4126761

26. Moratinos, J., D.W. Potter and S. Ellis, 1975. The influence of propranolol on catecholamine-induced changes in carbohydrate metabolism in the rabbit. Eur. J. Pharmacol., 32: 186-194. PMID: 1149805 
27. Moratinos, J., B. Olmedilla, I. de Pablos and M.D. Vigueras, 1986. $\alpha$-adrenoceptor involvement in catecholamine-induced hyperglycaemia in conscious fasted rabbits. Br. J. Pharm., 89: 55-66. PMID: 2879592

28. May, C.N., M.R. Dashwood, C.J. Whitehead and C.J. Mathias, 1990. Functional and autoradiographic studies to locate the sites at which clonidine acts to cause hyperglycaemia and inhibition of opiate-induced sympathetic outflow. Neuropharmacology, 29: 545-553. PMID: 2385326

29. DiTullio, N.W., L. Cieslinski, W.D. Matthews and B. Storer, 1984. Mechanisms involved in the hyperglycaemic response induced by clonidine and other alpa-2 adrenoceptor agonists. J. Pharmacol. Exp. Ther., 228: 168-173. PMID: 6141276

30. Angel, I. and S.Z. Langer, 1988. Adrenergicinduced hyperglycaemia in anaesthetized rats: Involvement of peripheral $\alpha_{2}$-adrenoceptors. Eur. J. Pharm., 154: 191-196. http://www.neuroassist.com/Epi\%20BBB\%202223 1.pdf

31. Reyes Toso, C.F., R.R. Rodriguez and A. Renauld, 1993. Blood sugar, serum insulin and serum nonesterified fatty acid levels during thiopentone anaesthesia in dogs. Can. J. Anaesth., 40: 38-45. PMID: 8425241

32. Nakadate, T., T. Nakaki, T. Muraki and R. Kato, 1980. Regulation of plasma insulin level by $\alpha_{2^{-}}$ adrenergic receptors. Eur. J. Pharmacol., 65: 421-424. PMID: 6105965

33. Nakadate, T., T. Nakaki, T. Muraki and R. Kato 1980. Adrenergic regulation of blood glucose levels: Possible involvement of post synaptic $\alpha_{2}$ type adrenergic receptors regulating insulin release. J. Pharmacol. Exp. Ther., 215: 226-230. PMID: 6109015
34. Knudtzon, J., 1984. Adrenergic effects on plasma levels of glucagon, insulin, glucose and free fatty acids in rabbits-influences of selective blocking drugs. Acta Physiol. Scand., 120: 353-361. PMID: 6146241

35. Metz, S.A., J.B. Halter and R.P. Robertson, 1978. Induction of defective insulin secretion and impaired glucose tolerance by clonidine, selective stimulation of metabloic $\alpha$-adrenergic pathways. Diabetes, 27: 554-562. PMID: 648745

36. Angel, I., S. Bidet and S.Z. Langer, 1988. Pharmacological characterization of the hyperglycaemia induced by $\alpha_{2}$-adrenoceptor agonists. J. Pharmacol. Exp. Ther., 246: 1098-103. PMID: 2901484

37. García-Barrado, M.J., C. Sancho, J. Palomero and J. Moratinos, 1998. Role of alpha2-adrenoceptors on the hyperglycaemic and insulin secretory effects derived from alphal-and beta-adrenoceptor stimulation in the rabbit. J. Auton. Pharmacol., 18: 287-295. PMID: 9831229

38. Berridge, T.L., J.C. Doxey, A.G. Roach and C.F. Smith, 1992. Selectivity profile of the alpha2adrenoceptor antagonist efaroxan in relation to plasma glucose and insulin levels in the rat. Eur. J. Pharmacol., 213: 205-12. PMID: 1355733

39. Goldberg, R.M. and O. Robertson, 1983. Yohimbine: A pharmacological probe for study of the $\alpha_{2}$-adrenoceptor. Phramacol. Rev., 35: 143-180. PMID: 6140686 